\title{
How Can We Measure Stock Market Returns? An International Comparison
}

\author{
Ben Said Hatem ${ }^{1}$ \\ ${ }^{1}$ Faculty of Law, Economics and Management of Jendouba, University of Jendouba, Jendouba, Tunisia \\ Correspondence: Ben Said Hatem, Faculty of Law, Economics and Management of Jendouba, University of \\ Jendouba, Jendouba, Tunisia.
}

\author{
Received: April 6, $2016 \quad$ Accepted: April 5,2017 Online Published: April 24, 2017 \\ doi:10.5539/ibr.v10n5p121 URL: https://doi.org/10.5539/ibr.v10n5p121
}

\begin{abstract}
The aim of our empirical work is to identify how we can measure stock returns. Stocks returns are approximated as the growth rate of market share price. We use two measures of stocks returns; return on assets, ROA, and return on equity, ROE. As a control variable, we use firm age. Our samples consists of 186 firms from United Kingdom and 186 firms from Ukraine studied over a period of 4 years from 2007 to 2010 . To this end, we estimate three models. Using the data panels methodology, we conclude that return on equity approximates better socks returns for United kingdom and Ukraine. We could not however find evidence on a significant association between return on assets and stock returns.
\end{abstract}

Keywords: stock return, firm performance, return on assets, return on equity

\section{Introduction}

Many studies tried to identify the determinants of stocks market return (Saadet, Gülin and Gökçe, 2011; Xinyi, Dimitris and Peiming, 2012). In this paper we identify what explains better stock returns; return on assets, ROA, or return on equity, ROE. To this end we examined a sample of two countries; United Kingdom and Ukraine. The next section will expose some studies explaining firm performance. In Section 3, we present our sample, the tested models and our variables. Section 4 interprets the descriptive statistics and our empirical results. A sensitivity analysis of our results by sector is made in section 5. The last section exposes our interpretations.

\section{The Literature Review}

Like Barth (1994), Barth et al. (1995), Barth et al. (1996), Eccher et al. (1996), and Nelson (1996), the article of Dan, Subramanyam, Robert (1999) tried to test the factors explaining market returns. The authors tests whether the net incomes estimate future cash flows of a firm. Examining a sample of 11425 firms, the authors found that the net income reflect better firm performance.

Similar to Molyneux and Thornton (1992), Demirguc-Kunt and Huizinga (1999), Staikouras and Wood (2004), Goddard, Molyneux, and Wilson (2004), Micco et al. (2007), PasiourasKosmidou (2007), and Flamini et al. (2009), Andreas and Gabrielle (2014) studied the factors explaining banks' profitability. As a measure of bank productivity, the authors use three ratios: return on average assets (ROAA), the return on average equity (ROAE) and the net interest margin (NIM). Examining a sample of 10165 banks in 118 countries over a period of 15 years from 1998 to 2012, the authors conclude that the economic level of each country affects the factors explaining profitability of banks.

Like Athanasoglou, Brissimis\& Delis (2008), Kosmidou (2008), Pervan, Pervan\&Guadagnino (2010), and Košak\&Čok (2008),Marijuana, Klime and Sandra (2014) tested determinants of profitability of Macedonian banks. Using a sample of 16 banks for a period of 6 years from 2005 to 2010, the authors report that good management of banks means higher performance. Furthermore, liquidity risk and solvability risk affect profitability of banks.

\section{Data and Methodology}

\subsection{Sample Selection}

In order to properly study firm performance, measured by stocks market return, we examine a sample of 186 firms in United Kingdom and 186 in Ukraine over a period of 4 years from 2007 to 2010. Data were used from the « Amadeus » database. 


\subsection{Choice of Variables and Hypotheses}

The dependent variables:

- Stock returns: similarly to work Dan et all (1999), we approximate firm performance by the return of the share prices.

The independent variables:

- Return on assets, ROA: we approximate firm performance by the ratio of return on assets identified as the ratio of net profit over total assets. Higher firm performance will increase shareholder wealth, and then, market return. Hypothesis 1: return on assets, ROA, is positively related to stocks market return.

- Return on equity, ROE: Following the work Ben said (2014), we measure firm performance by the ratio of return on equity approximated as the ratio of net profit over shareholders equity. Higher firm performance will increase share price, and then, market return. Hypothesis 2: return on equity, ROE, is positively related to stocks market return.

- Firm age: as a control variable, we will consider, only, firm age. Firm age is estimated as the number of years between creation year and current year. Generally, older firms are more notoriety. Therefore, shareholders often try to buy more shares from older firms. we assume, then, a higher share price and an enhance in shareholder wealth and market return. Hypothesis 3: firm age positively affects market return.

Table 1. Variables and expected signs

\begin{tabular}{cccc}
\hline Variables & Abbreviation & Formulation & Expected sign \\
\hline Stock returns & return & growth rate of share price & Dependant variable \\
Firm performance & ROA & Net income / total assets & + \\
Firm performance & ROE & Net income / shareholder's equity &.+ \\
Firm age & age & Number of years & + \\
\hline
\end{tabular}

3.3 The Models

Following the methodology of Dan, Subramanyam and Robert (1999), we use the following models:

$$
\begin{aligned}
& \operatorname{Return}_{i t}=\alpha_{0}+\alpha_{1} * R O A_{i t}+\alpha_{2} * A G E_{i t}+\varepsilon_{i t} \\
& \text { Return }_{i t}=\alpha_{0}+\alpha_{1} * R O E_{i t}+\alpha_{2} * A G E_{i t}+\varepsilon_{i t} \\
& \text { Return }_{i t}=\alpha_{0}+\alpha_{1} * R O A_{i t}+\alpha_{3} * R O E_{i t}+\alpha_{3} * A G E_{i t}+\varepsilon_{i t}
\end{aligned}
$$

\section{The Empirical Results}

\subsection{Descriptive Statistics}

Our sample consists of 186 firms from Ukraine distributed operating in the following sectors: 9 firms from the service sector, 6 firms from the real estate sector, 47 firms from professional activities, 14 firms from mining and agriculture sector and 110 firms from the manufacturing sector. As for the sample of United Kingdom, it contains 186 firms operating in the following sectors: 65 firms from the service sector, 23 firms from the real estate activities, 29 firms from professional activities, 20 firms from mining and agriculture sector and 49 from the manufacturing firms. We can conclude that in United Kingdom, firms are distributed in the service sector and in Ukraine most corporations operate in the manufacturing sector.

Table 2. Distribution of our sample into activity sectors

\begin{tabular}{ccccccc}
\hline & Service & Real estates activities & Professionals activities & $\begin{array}{c}\text { Mining and } \\
\text { agriculture }\end{array}$ & Manufacturing & Total \\
\hline Ukraine & 9 & 6 & 47 & 14 & 110 & 186 firms \\
UK & 65 & 23 & 29 & 20 & 49 & 186 firms \\
\hline
\end{tabular}

Statistics (table 3) show that firms of United kingdom are more profitable than firms in Ukraine. The mean values are equal to 0,0586 and 0,158 for return on assets, ROA, and return on equity, ROE, respectively. However, we conclude to a higher value of return on market share price for firms in Ukraine. In fact, growth rate of share price is equal to 0,239 . Furthermore, share price for firms in United kingdom increases, annually, by $12,7 \%$. We conclude that firms in Ukraine are older then firms in United kingdom with a mean value of 51,309 years. The average age of firms in United kingdom is 34,903 years with a minimum of 1 year and a maximum of 125 years. Finally, profitability, estimated by return on assets and return on equity, market return and age for firms in Ukraine are riskier than United kingdom. Standard deviations are equal to $0,121,0,2070,3,832$ and 37,106, respectively. 
Table 3. Descriptive statistics

\begin{tabular}{llllll}
\hline & \multicolumn{5}{c}{ United King dom } \\
\hline & OBS & MEAN & STD DEV & MIN & MAX \\
\hline ROA & 718 & 0,0586 & 0,0962 & $-0,785$ & 0,649 \\
ROE & 669 & 0,158 & 0,205 & $-0,905$ & 0,977 \\
Return & 524 & 0,127 & 1,00429 & $-0,990$ & 14,427 \\
AGE & 728 & 34,903 & 34,699 & 1 & 125 \\
\hline \multicolumn{7}{r}{} & MEAN & Ukraine & MIN & MAX \\
\hline ROA & OBS & STD DEV & $-0,901$ & 0,600 \\
ROE & 736 & 0,00559 & 0,121 & $-0,987$ & 0,975 \\
R & 681 & 0,0386 & 0,270 & $-0,991$ & 57,836 \\
AGE & 376 & 0,239 & 3,832 & 2 & 161 \\
\hline 4.2 What Determines Firm Performance? & 51,309 & 37,106 & &
\end{tabular}

The results on the factors explaining market return are presented in table 4 . As a dependant variable, we use market return calculated as growth rate of share price. Initially, we use, alternatively, as independent variables, return on assets, ROA, and return on equity, ROE. In the third model, we use theses two independents variables. As a control variable, we use, only, firm age. The highest correlation coefficients equal to $15,24 \%$ for United kingdom and $5,23 \%$ for Ukraine. It seems that the independents variables of the third model explain better market return for United Kingdom and Ukraine. Across all specifications, we could not find affirmation on a positive association between profitability approximated by return on assets, ROA, and market return. All coefficients on this measure are not statistically significant. As for the effect of profitability measured by return on equity ratio the results are mixed. Our hypothesis 2 is checked, only, for Ukraine. Higher return on equity ratio leads to higher growth rate of share price. This result means that investors in Ukraine market try to buy shares of profitable firms. However, we conclude to a negative and a statistically significant effect of return on equity on market return for firms of United kingdom. This result indicates a decrease in share price for profitable firms in United kingdom. Finally, regarding firm age, we conclude to a positive and a statistically significant relationship, for all specifications, between firm age and market return. This findings means that older firms in United kingdom and Ukraine recorded an increase in their share prices.

Table 4. Determinants of stocks market returns

\begin{tabular}{|c|c|c|c|}
\hline & \multicolumn{3}{|c|}{ United King dom } \\
\hline & Specification 1 & Specification 2 & Specification 3 \\
\hline & Return & Return & Return \\
\hline $\mathrm{C}$ & $-14,550^{* * *}$ & $-14,0654^{* * *}$ & $-14,0485^{* * *}$ \\
\hline ROA & 0,0632 & & 0,107 \\
\hline ROE & & $-1,00819^{* * *}$ & $-1,0267^{* *}$ \\
\hline Age & $0,404^{* * *}$ & $0,386^{* * *}$ & $0,385^{* * *}$ \\
\hline OBS & 524 & 485 & 485 \\
\hline R squared(\%) & 14,36 & 15,24 & 15,24 \\
\hline \multirow[t]{4}{*}{ Prob $>F$} & 0 & 0 & 0 \\
\hline & & Ukrain & \\
\hline & Specification 1 & Specification 2 & Specification 3 \\
\hline & Return & Return & Return \\
\hline $\mathrm{C}$ & $38,490^{* * *}$ & $40,412^{* * *}$ & $-39,336^{* * *}$ \\
\hline ROA & 3,547 & & $-5,618$ \\
\hline ROE & & $2,176^{*}$ & $3,818^{*}$ \\
\hline Age & $0,711^{* * *}$ & $0,749^{* * *}$ & $0,731^{* * *}$ \\
\hline OBS & 375 & 351 & 351 \\
\hline R squared(\%) & 3,55 & 4,85 & 5,23 \\
\hline Prob $>F$ & 0,0165 & 0,0058 & 0,0113 \\
\hline
\end{tabular}

Note.,,,,$:$ : significance at $10 \%, 5 \%$ and $1 \%$ levels respectively.

\section{Explaining Firm Performance and the Effect of Activity Sectors}

We try to determine the effect of activity sectors on explaining stocks market return. We considered five activity sectors; the service sector, the real estate sector, the professional sector, agriculture and mining sector and the manufacturing sector. We tested third model. 
Table 5. Role of activity sectors in explaining determinants of stocks market returns

\begin{tabular}{|c|c|c|c|c|c|}
\hline & \multicolumn{5}{|c|}{ United Kingdom } \\
\hline & Service & Real estate & Professional & Agriculture minining & Manufacturing \\
\hline & Return & Return & Return & Return & Return \\
\hline $\mathrm{C}$ & $-8,439^{* *}$ & $-12,222^{* *}$ & $-9,334^{* * *}$ & $-10,896^{*}$ & $-23,158^{* * *}$ \\
\hline ROA & $-7,207^{*}$ & 9,202 & $-1,739$ & $-8,0760$ & $6,469^{* * *}$ \\
\hline ROE & 0,0865 & $-5,282$ & 0,608 & 2,408 & $-1,963^{* * *}$ \\
\hline Age & $0,303^{* *}$ & $0,317^{* *}$ & $0,328^{* * *}$ & $0,390^{* *}$ & $0,446^{* * *}$ \\
\hline OBS & 160 & 62 & 70 & 53 & 140 \\
\hline $\mathrm{R}$ squared(\%) & 9,47 & 20,25 & 23,19 & 18,14 & 48,96 \\
\hline \multirow[t]{4}{*}{ Prob $>$ F } & 0,0194 & 0,0410 & 0,0120 & 0,0895 & 0 \\
\hline & \multicolumn{5}{|c|}{ Ukraine } \\
\hline & Se rvice & Real estate & Professional & Agriculture minining & Manufacturing \\
\hline & Return & Return & Return & Return & Return \\
\hline $\mathrm{C}$ & 0,990 & 9,864 & $-35,852^{*}$ & $-34,280^{* * *}$ & $35,609^{* * *}$ \\
\hline ROA & 32,250 & 64,442 & $-23,490$ & $-8,0974$ & 1,585 \\
\hline ROE & $-6,814$ & $-17,915$ & $21,517^{* *}$ & $6,572^{*}$ & $-0,224$ \\
\hline Age & $-0,0320$ & $-0,144$ & $1,574^{*}$ & $0,685^{* * *}$ & $0,502^{* * *}$ \\
\hline OBS & 5 & 10 & 102 & 30 & 204 \\
\hline R squared(\%) & 1,04 & $-42,61$ & 14,47 & 49,52 & 23,84 \\
\hline Prob $>F$ & 0,6061 & 0,9549 & 0,0238 & 0,0076 & 0 \\
\hline
\end{tabular}

Note. ${ }^{*},{ }^{* * * * * *}$ : significance at $10 \%, 5 \%$ and $1 \%$ levels respectively.

The highest correlation measures are equal to $48,96 \%$ for the manufacturing firms of United kingdom, and $49,52 \%$ for agriculture and mining firms of Ukraine (table 5). We could not find affirmation on a positive relationship between profitability, measured by return on assets, ROA, and stocks market return for firms of Ukraine. However, the results for United kingdom are mixed. We conclude to a negative and a statistically significant impact of profitability, measured by ROA, for the corporations belonging to service sector. Furthermore, our hypothesis is retained for the manufacturing firms of United kingdom. Regarding the variable return on equity ratio, ROE, we reported a positive and a statistically significant effect on stocks market return for firms of Ukraine operating in the professional activities and agriculture and mining. However, we found a negative relationship for the manufacturing firms of United kingdom. As of our control variable, our research hypothesis is retained for all specifications, except, for firms of Ukraine operating in the service and real estate sectors.

\section{Conclusion}

Many works attempted to highlight the determinants of firm performance. In our paper, we try to determine how we can measure firm performance. In fact, firm performance was approximated using growth rate of share price. As independent variables that highlight firm performance, we used two ratios; return on assets, ROA, and return on equity, ROE. As control variable, we used, only, firm age. The results report that profitability measured by return on assets does not explain firm performance in United kingdom and Ukraine. Howe ver, we concluded to a positive and a statistically significant relationship between return on equity and stocks market return for firms of Ukraine. This finding do not rejects our second hypothesis. Higher profitable firms in United kingdom, measured by return on equity, have lower market return. This result does not accept our second hypothesis. We found, also, a positive interdependence between firm age and stocks market return for United Kingdom and Ukraine. This finding do not rejects our third hypothesis. Finally, we studied the effect of activity sectors on explaining firm performance. The results highlight that our first hypothesis is retained for the manufacturing firms of United kingdom. Our se cond hypothesis is retained for professional activities and agriculture and mining sector. Finally, we could not find affirmation on a positive relationship between firm age and stocks market return for firms in Ukraine operating in the service and real estate sectors. 


\section{References}

Andreas, D., \& Gabrielle, W. (2014). The determinants of commercial banking profitability in low-,middle-, and high-income countries. The Quarterly Review of Economics and Finance, 54(2014), 337-354. https://doi.org/10.1016/j.qref.2014.03.001

Athanasoglou, P. P., Brissimis, S. N., \& Delis, M. D. (2008). Bank-specific, industry-specific and macroeconomic determinants of bank profitability. Journal of International Financial Markets, Institutions and Money, 18(2), 121-136. https://doi.org/10.1016/j.intfin.2006.07.001

Barth, M. E. (1994). Fair value accounting: Evidence from investment securities and the market valuation of banks. The Accounting Review, 69, $1 \oplus 25$.

Barth, M. E., Beaver, W. H., \& Landsman, W. R. (1996). Value-relevance of banks fair value disclosures under SFAS 107. The Accounting Review, 71, $513 \doteq 537$.

Barth, M. E., Landsman, W. R., \& Wahlen, J. M. (1995). Fair value accounting: effects on banks earnings volatility, regulatory capital, and value of contractual cash flows. Journal of Banking and Finance, 19, 577Đ605. https://doi.org/10.1016/0378-4266(94)00141-O

Ben, S. H. (2014). Determinants of Ownership Structure: A Comparison of Common and Civil Law Countries". International Business Research, 7(10), 2014. https://doi.org/10.5539/ibr.v7n10p118

Dan Dhaliwal, K. R., \& Subramanyam, R. T. (1999). Is comprehensive income superior to net income as a measure of Prmperformance. Journal of Accounting and Economics, 26, $43 Đ 67$.

Demirguc-Kunt, A., \& Huizinga, H. (1999). Determinants of commercial bank interest margins and profitability: Some international evidence. World Bank Economic Review, 13(2), 379-408. https://doi.org/10.1093/wber/13.2.379

Eccher, E. A., Ramesh, K., \& Thiagarajan, S. R. (1996). Fair value disclosures by bank holding companies.Journal of Accounting and Economics, 22, 79Đ117. https://doi.org/10.1016/S0165-4101(96)00438-7

Flamini, V., McDonald, C., \& Schumacher, L. (2009). The determinants of commercial bank profitability in Sub-Saharan Africa. IMF Working Paper No. 09/15. https://doi.org/10.5089/9781451871623.001

Goddard, J., Molyneux, P., \& Wilson, J. (2004). The profitability of European banks: Across-sectional and $\begin{array}{lllll}\text { dynamic panel } & \text { analysis. }\end{array}$ https://doi.org/10.1111/j.1467-9957.2004.00397.x

Kosak, M., \& Cok, M. (2008). Ownership structure and profitability of the banking sector: The evidence from the SEE region. ZbornikradovaEkonomskogFakulteta u Rijeci, 26(1), 93-122.

Kosmidou, K. (2008). The determinants of banks' profits in Greece during the period of EU financial integration. Managerial Finance, 34(3), 146-159. https://doi.org/10.1108/03074350810848036

Marijana, Ć., Klime, P., \& Sandra, P. (2014). Profitability Determinants of the Macedonian Banking Sector in Changing Environment. Procedia - Social and Behavioral Sciences, 44(2012), 406-416. https://doi.org/10.1016/j.sbspro.2012.05.045

Micco, A., Panizza, U., \& Yanez, M. (2007).Bank ownership and performance. Does politics matter? Journal of Banking and Finance, 31(1), 219-241.https://doi.org/10.1016/j.jbankfin.2006.02.007

Molyneux, P., \& Thornton, J. (1992). Determinants of European bank profitability: Anote. Journal of Banking and Finance, 16(6), 1173-1178. https://doi.org/10.1016/0378-4266(92)90065-8

Nelson, K. (1996). Fair value accounting for commercial banks: An empirical analysis of SFAS no. 107. The Accounting Review, $71,161 Đ 182$.

Pasiouras, F., \& Kosmidou, K. (2007).Factors influencing the profitability of domestic and foreign commercial banks in the European Union. Research in International Business and Finance, 21(2), 222-237. https://doi.org/10.1016/j.ribaf.2006.03.007

Pervan, M., Pervan, I., \& Guadagnino, A. (2010).Market Structure and Profitability of Croatian Commercial Banks. The Business Review, 20(1), 209-216.

Saadet, K., Gülin, V., \&Gökçe, T. (2011). The impact of interest rate and exchange rate volatility on banks' stock returns and volatility: Evidence from Turkey. Economic Modelling, 28(2011), 1328-1334. https://doi.org/10.1016/j.econmod.2011.01.015 
Staikouras, C., \& Wood, G. (2004). The determinants of European bank profitability. International Business and Economics Research Journal, 3(6), 57-68.

Xinyi, L., Dimitris, M., \& Peiming, W. (2012). Stock market volatility and equity returns: Evidence from a two-state Markov-switching model with regressors. Journal of Empirical Finance, 19(2012), 483-496. https://doi.org/10.1016/j.jempfin.2012.04.011

\section{Copyrights}

Copyright for this article is retained by the author(s), with first publication rights granted to the journal.

This is an open-access article distributed under the terms and conditions of the Creative Commons Attribution license (http://creativecommons.org/licenses/by/4.0/). 